Article

\title{
Impacts of Climatic and Agricultural Input Factors on the Water Footprint of Crop Production in Jilin Province, China
}

\author{
Xiaoxue Zheng ${ }^{1}$, Lijie Qin ${ }^{1, *(1)}$ and Hongshi He ${ }^{1,2}$ \\ 1 Key Laboratory of Geographical Processes and Ecological Security in Changbai Mountains, \\ Ministry of Education, School of Geographical Sciences, Northeast Normal University, Changchun 130024, \\ China; zhengxx856@nenu.edu.cn (X.Z.); hehs100@nenu.edu.cn (H.H.) \\ 2 School of Natural Resources, University of Missouri, Columbia, MO 65211, USA \\ * Correspondence: qinlj953@nenu.edu.cn; Tel.: +86-130-7438-2964
}

Received: 28 June 2020; Accepted: 22 August 2020; Published: 25 August 2020

\begin{abstract}
Water consumption ensures crop production and grain security, and is influenced by many factors. Analyzing the impact factors of water consumption during crop production will be beneficial to the full use of water resources and crop growth. Jilin Province is one of the major crop production areas in China and is facing water shortages. Using the water footprint as an indicator, this study evaluated the water consumption of crop production in Jilin Province during 2000-2016, explored the impacts of climatic and agricultural input factors on the water consumption of crop production, and identified the most influential factors in years under different levels of rainfall. The results indicate that the crop water footprint exhibited a decreasing trend during 2000-2016, and the most influential factors of the crop water footprint changed over the years with different levels of rainfall. Precipitation and the effective irrigation area were the most influential factors in the drought year, and accumulated temperature, machinery power, and chemical fertilizer consumption were the most influential factors in normal and humid years. The most influential factors of the crop water footprint differed in different regions with the differences in natural and human interfered conditions. Identifying the impacts of the most influential factors on the water consumption of crop production would be conducive to optimizing farmland management and achieving sustainable agricultural production.
\end{abstract}

Keywords: water footprint; crop production; climatic factors; agricultural input factors; Jilin Province

\section{Introduction}

Grain security is closely related to social well-being, stabile and sustainable economic development [1], and crop production guarantees grain security. Crop growth requires large volumes of water during the growing period. On a global scale, nearly $50 \%$ of water withdrawals are consumed for crop production [2]. Therefore, water consumption is an important aspect of maintaining the sustainable crop production. However, water consumption in crop production is influenced by many factors [3-5]. Accurate accounting of water consumption in crop production and analyzing the impact factors are necessary.

The water footprint (WF) concept was introduced by Hoekstra and Hung, referring to the amount of water needed to produce products and services [6]. The mathematical formulations of the WF provide a novel approach for assessing water consumption in crop production [7,8]. The WF of a crop is defined as the volume of freshwater both consumed in the field and used to dilute pollutants during crop growth [9]. The WF includes three components of water consumption: the green WF (the consumption of rainwater stored in the soil for crop growth); the blue WF (irrigation water 
(surface and groundwater) consumption used for crop growth); and the gray WF (the volume of freshwater required to assimilate the load of pollutants during crop growth) [10]. The WF of crop production differs from the traditional accounting method used for agricultural water consumption, since it measures not only irrigation water consumption (blue water) but also rainwater consumption (green water) and the amount of water used to dilute pollutants (gray water), providing the most extended and complete water accounting method. For the importance of green water, Flach et al. assessed the water use in Brazil for four major rainfed crops (cotton, maize, soybean, and wheat) and emphasized the positive role of green water in crop production [11]. As for the gray water, Borsato et al. evaluated the gray WF of crops under the effects of agricultural practices and considered the gray water not to be ignorable in agricultural water use [12].

The CROPWAT Model is a common approach to calculate crop WF, which employs many climate indices, e.g., air temperature, precipitation, wind speed, relative humidity, sunshine hours, etc., to confirm the field evapotranspiration during crop growth, and the climatic conditions determine blue $\mathrm{WF}$, green WF, layout and structure of crop production [13]. Besides climatic conditions, the agricultural management activities, e.g., irrigation, fertilization, mechanization, etc., influence the quantity and quality of crop yield and also determine water consumption. Therefore, the crop WF is influenced by many factors, including natural and related factors to field management. However, previous studies on the WF of crop production mainly focused on the concept, quantification, and spatiotemporal variations on global, national, and regional scales [14-19], and few involved the impact factors.

Among the studies regarding the impact factors for the WF of crop production, Cao et al. used the partial least-squares regression to assess the driving factors of the crop WF in Jiangsu Province of China, and they found that the main climatic and anthropogenic factors were precipitation and irrigation parameters, respectively [20]. In the study of Arunrat et al., precipitation had a more obvious impact on the WF of rice in Thailand [21], which was similar to the results about the WF of rice in China found by Chen et al. [22]. Precipitation was also confirmed to be more influential to the water use of wheat production in Zimbabwe and the sugarcane in Nigeria [23,24]. By the path analysis, the studies of Sun et al. indicated that the main climatic factors on the WF of maize in Beijing and wheat in mainland China were precipitation and sunshine hours, respectively $[25,26]$. Considering the agricultural inputs, machinery power had a larger impact on the WF of maize in Beijing and Northeast China [25,27]. Irrigation was more important for the WF of wheat in Zimbabwe, Germany, Italy, and the irrigation area of China [23,28,29], and was also vital to the WF of maize and soybean in Uruguay [30]. Using the Life Cycle Assessment (LCA), Lovarelli et al. found that fertilization played a more important role in the WF of maize production in Northern Italy [31]. Generally, these studies adopted one analysis method and analyzed the impact factors of one single crop at a regional scale during a study period. There were few studies which analyzed the impact factors of multiple-type crops over years with different levels of rainfall and with multiple methods and obtained optimal controlling factors on the WF of crop production in different subareas. Therefore, studying the impact factors of crop WF with multiple methods and multiple-type crops would be conducive to identifying the most influential factors of crop WF and analyzing the spatiotemporal variations of the most influential factors, and would also help to deepen the understanding of the concept of WF. Furthermore, for the calculation of the WF of crop production, previous studies usually adopted the optimal option called the 'crop water requirement option' in the CROPWAT model, assuming that the crop was fully irrigated during its growth and that the growing process was not limited by the water supplies [10]. However, in realistic field production, not all crops are adequately irrigated due to the limitations of local water resources. When full irrigation is not possible, the 'irrigation schedule option' in the CROPWAT model should be adopted to calculate the WF of crop production. Thus, the calculations of crop WF should be varied with changes in irrigation conditions of crops.

Jilin Province is a typical major crop production region in China [32] and is obviously different in the natural, social, and economic conditions among subregions [33-35]. This study took Jilin Province as the study area and could reflect the characteristics of crop production and regional differences. 
Three basic crops (rice, maize, and soybean) were chosen as the study objects. Because of the vast area of cultivated land, rainfall is the main source of water consumption for crop production, and drought, normal, and humid years were chosen as the typical years to analyze the crop WF and impact factors, which could exhibit the changes in the crop WF and impact factors under different rainfall conditions. To accurately calculate the WF of the different crops, this study adopted different options in the CROPWAT model in accordance with the planting and irrigation characteristics of the local crops. Combining path analysis and a geographically weighted regression model, this study assessed the impacts of climatic and agricultural input factors on the WF of crop production.

The study aimed to (1) analyze the temporal and spatial variations of crop WF in Jilin Province during 2000-2016; (2) identify the most influential factors of the WF of crop production in years under different levels of rainfall; and (3) obtain the optimal managing factors in different regions of Jilin Province. Results from this study provide a basis for the development of practicable strategies for agricultural activities and the rational use of water resources for crop production under different conditions.

\section{Materials and Methods}

\subsection{Study Area}

Jilin Province is located in Northeast China $\left(40^{\circ} 52^{\prime}-46^{\circ} 18^{\prime} \mathrm{N}, 121^{\circ} 38^{\prime}-131^{\circ} 19^{\prime} \mathrm{E}\right)$ and is divided into 48 counties (Figure 1). This province has a temperate continental monsoon climate. The annual average temperature is $5.9^{\circ} \mathrm{C}$. The annual precipitation is $608.3 \mathrm{~mm}$, of which summer rain contributes $>80 \%$, and the precipitation decreases gradually from east to west across the province. The eastern Jilin Province is a mountainous area, the middle is a plain area where the soil is fertile and vast, and the western Jilin Province is a meadow area where salinization is serious, and the soil fertility is lower [33,34]. Based on the characteristics of its diverse climate, topography, and soil, Jilin Province is divided into four regions, namely, the eastern, central eastern, central, and western regions (Figure 1).

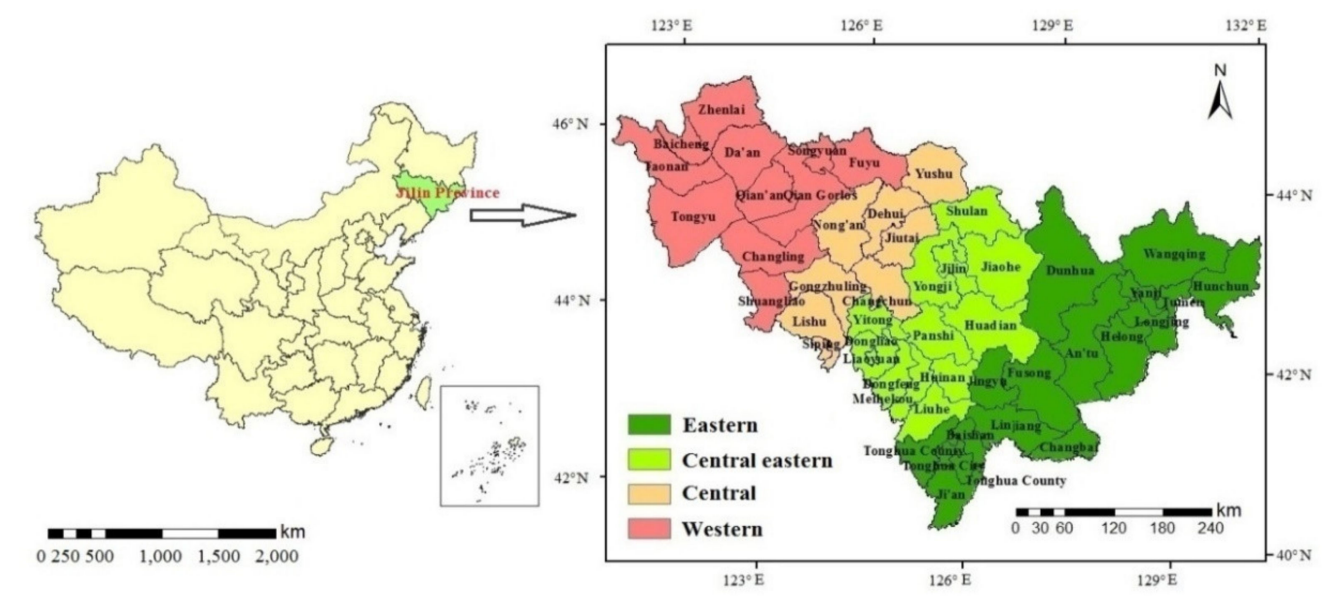

Figure 1. Location of Jilin Province and its counties.

Jilin Province is one of the most important crop production regions in China and plays an important role in ensuring national grain security [32]. Maize, rice, and soybean are the main crops grown in Jilin Province. These three crops consume nearly 70\% of the total freshwater used for crop production in Jilin Province, and the sum of their yield accounts for nearly $95 \%$ of the province's total crop yield [36,37]. Their planting area accounts for $93 \%$ of the province's total crop planting area [37]. Therefore, this study chose these three major crops to show the general characteristics of the water consumption for crop production in Jilin Province.

The development of the economy provides basic conditions for agricultural production in Jilin Province. The gross domestic product (GDP) exhibited a significant developing tendency, which was 
182 billion yuan in 2000 and 1488 billion yuan in 2016 [38], and led to the increase in agricultural input continuously. The mechanization in crop production was gradually popularized, and chemical fertilizers were widely used, which greatly promoted the efficiency of crop production. Whereas the levels of economic development among the regions are uneven, the central region has the highest level of economic development [35]. Moreover, the cultivated area in the central and western regions is vast, and in the eastern and central eastern regions is limited because of the topography. The main agricultural management elements of the studied crops (rice, maize, and soybean) included the input of machinery power (including mechanized cultivation and mechanized seeding), fertilization, and irrigation (adequate irrigation for rice, inadequate irrigation for maize, and no irrigation for soybean).

\subsection{WF Calculation of Crop Production}

The WF of crop production in Jilin Province was determined by $W F_{\text {rice, }}, W F_{\text {maize }}, W F_{\text {soybean }}$, and their yields.

$$
W F_{\text {crop }}=\frac{W F_{\text {rice }} \times Y_{\text {rice }}+W F_{\text {maize }} \times Y_{\text {maize }}+W F_{\text {soybean }} \times Y_{\text {soybean }}}{Y_{\text {rice }}+Y_{\text {maize }}+Y_{\text {soybean }}}
$$

where $W F_{\text {rice, }} W F_{\text {maize, }}$ and $W F_{\text {soybean }}$ are the $W F$ of rice, maize, and soybean $\left(\mathrm{m}^{3} / \mathrm{kg}\right)$, respectively, and $Y_{\text {rice, }} Y_{\text {maize }}$, and $Y_{\text {soybean }}$ are the total yields of rice, maize, and soybean $(\mathrm{kg})$, respectively.

$W F_{\text {rice }}, W F_{\text {maize, }}$ and $W F_{\text {soybean }}$ were estimated following the calculation framework developed by Hoekstra et al. [10]. The $W F_{\text {total }}$ of one crop is the total water consumption during the crop growth process, including the green WF, blue WF, and gray WF.

$$
W F_{\text {total }}=W F_{\text {green }}+W F_{\text {blue }}+W F_{\text {gray }}
$$

where $W F_{\text {total }}$ is the total WF of one crop $\left(\mathrm{m}^{3} / \mathrm{kg}\right), W F_{\text {green }}$ is the green $W F\left(\mathrm{~m}^{3} / \mathrm{kg}\right), W F_{\text {blue }}$ is the blue $\mathrm{WF}\left(\mathrm{m}^{3} / \mathrm{kg}\right)$, and $W F_{\text {gray }}$ is the gray WF $\left(\mathrm{m}^{3} / \mathrm{kg}\right)$.

The calculation of the gray WF was estimated as follows:

$$
W F_{\text {gray }}=\frac{(\alpha \times A R) /\left(c_{\max }-c_{\text {nat }}\right)}{Y}
$$

where $Y$ is the crop yield $\left(\mathrm{kg} / \mathrm{hm}^{2}\right), A R$ is the quantity of nitrogen fertilizer applied $\left(\mathrm{kg} / \mathrm{hm}^{2}\right), \alpha$ is the leaching run-off fraction of nitrogen fertilizer, $c_{\max }$ is the maximum acceptable concentration of nitrogen $\left(\mathrm{kg} / \mathrm{m}^{3}\right)$, and $c_{\text {nat }}$ is the natural concentration of nitrogen $\left(\mathrm{kg} / \mathrm{m}^{3}\right)$. In this study, $\alpha$ was $10 \%$ of nitrogen fertilizer, $c_{\max }$ was $0.01 \mathrm{~kg} / \mathrm{m}^{3}$, following the environmental quality standards for surface water in China (GB3838-2002) [39], and $c_{\text {nat }}$ was assumed to be 0.

The nitrogen fertilizer applied $(A R)$ to the crops in the different regions is shown in Table 1.

Table 1. Nitrogen fertilizer applied $(A R)$ of rice, maize, and soybean in different regions of Jilin Province $\left(\mathrm{kg} / \mathrm{hm}^{2}\right)$.

\begin{tabular}{ccccc}
\hline & Eastern & Central Eastern & Central & Western \\
\hline Rice & 170 & 180 & 200 & 230 \\
Maize & 160 & 170 & 190 & 200 \\
Soybean & 50 & 55 & 60 & 65 \\
\hline
\end{tabular}

Sources: [40-42].

The green WF and blue WF were determined by crop water use and crop yield and were calculated using the CROPWAT 8.0 model [13]. The model offers two alternative calculation options: the 'crop water requirement option' (assuming optimal conditions during crop growth) and the 'irrigation schedule option' (including the possibility to specify the actual irrigation supply in time) [10]. In Jilin 
Province, rice, maize, and soybean have different planting and irrigation patterns. Therefore, this study adopted different options for calculating their green WF and blue WF, namely, the 'crop water requirement option' for the green WF and blue WF of rice and the 'irrigation schedule option' for the green WF and blue WF of maize and soybean.

Rice in Jilin Province is fully irrigated during its growth, according to the optimal conditions. Under the 'crop water requirement option', the $W F_{\text {green }}$ and $W F_{\text {blue }}$ of rice were computed as:

$$
\begin{gathered}
W F_{\text {green }}=\frac{10 \times E T_{\text {green }}}{Y} \\
W F_{\text {blue }}=\frac{10 \times\left(E T_{\text {blue }}+P L\right)}{Y}
\end{gathered}
$$

where $E T_{\text {green }}$ is the green water evapotranspiration $(\mathrm{mm}), E T_{\text {blue }}$ is the blue water evapotranspiration $(\mathrm{mm}), Y$ is the rice yield $\left(\mathrm{kg} / \mathrm{hm}^{2}\right)$, the factor of 10 converts the water depth $(\mathrm{mm})$ into the water volume per area $\left(\mathrm{m}^{3} / \mathrm{hm}^{2}\right)$, and $P L$ is the amount of percolation to groundwater $(\mathrm{mm})$ obtained from a field investigation and a review of the literature [43-45] (Table 2).

Table 2. Amount of percolation $(P L)$ during rice production in different regions of Jilin Province.

\begin{tabular}{ccccc}
\hline & Eastern & Central Eastern & Central & Western \\
\hline Daily percolation $(\mathrm{mm} / \mathrm{d})$ & 1.5 & 2.0 & 2.6 & 1.3 \\
Total percolation $(\mathrm{mm})$ & 195 & 260 & 338 & 169 \\
\hline
\end{tabular}

The average period of rice growth is approximately $130 \mathrm{~d}$ [46].

The $E T_{\text {green }}$ and $E T_{\text {blue }}$ were then calculated as

$$
\begin{gathered}
E T_{\text {green }}=\min \left(E T_{c}, P_{\text {eff }}\right) \\
E T_{\text {blue }}=\max \left(0, E T_{c}-P_{\text {eff }}\right)
\end{gathered}
$$

where $E T_{C}$ is the evapotranspiration calculated using the Penman-Monteith model (mm) [47-49], and $P_{\text {eff }}$ is the effective precipitation during the growing period $(\mathrm{mm})$, calculated according to the method developed by the US Department of Agriculture [50].

$$
P_{\text {eff }}= \begin{cases}P(4.17-0.2 P) / 4.17 & P<8.3 \mathrm{~mm} \\ 4.17+0.1 P & P \geq 8.3 \mathrm{~mm}\end{cases}
$$

where $P$ is the precipitation at a daily time step $(\mathrm{mm})$.

In Jilin Province, the planting area of maize is the largest, accounting for nearly $75 \%$ of the total crop area. The maize yield is also greater than that of other crops, accounting for nearly $77 \%$ of the total crop yield. Due to the limited water resources and the wide planting area, maize cannot be irrigated adequately during the growth period. The maize irrigation mode is to sow with water, in which the maize seed is irrigated with a small quantity of water at the sowing time, creating a microenvironment with sufficient soil water to ensure germination and seedling establishment [51,52]. The maize then receives no irrigation water at any other stage.

Under the 'irrigation schedule option', the $W F_{\text {blue }}$ and $W F_{\text {green }}$ of maize were:

$$
\begin{gathered}
W F_{\text {blue }}=\frac{I U}{Y} \\
W F_{\text {green }}=\frac{10 \times E T_{c}-I U}{Y}
\end{gathered}
$$

where $I U$ is the water used on the sowing day $\left(\mathrm{m}^{3} / \mathrm{hm}^{2}\right)$, obtained from a field investigation and a literature review $[53,54]$ (Table 3). 
Table 3. Irrigation use $(I U)$ of maize in different regions of Jilin Province in years under different levels of rainfall $\left(\mathrm{m}^{3} / \mathrm{hm}^{2}\right)$.

\begin{tabular}{ccccc}
\hline & Eastern & Central Eastern & Central & Western \\
\hline Humid year & - & 20 & 30 & 40 \\
Normal year & - & 30 & 40 & 50 \\
Drought year & - & 50 & 60 & 70 \\
\hline
\end{tabular}

Maize used no irrigation water in the eastern region because of the humid local climate.

Soybean is also one of the major crops in Jilin Province. Soybean grows depending on the natural rainfall and uses no irrigation. Under the 'irrigation schedule option', the blue WF of soybean was 0 , and the green WF of soybean was:

$$
\begin{gathered}
W F_{\text {blue }}=0 \\
W F_{\text {green }}=\frac{10 \times E T_{c}}{Y}
\end{gathered}
$$

\subsection{Path Analysis}

Wright proposed the concept of path analysis in 1921, which analyzes the correlation between different variables [55]. When there are many independent variables, and their relationships are complicated, it is appropriate to use path analysis. Path analysis separates the correlation between independent and dependent variables into two parts: the direct influence of the independent variables and their indirect influence through other related independent variables [56]. The path coefficient is defined as the direct influence of the independent variable on the dependent variable. In multivariate studies, path analysis has been proven more effective than other methods for identifying the most influential factors.

Suppose that there are several independent variables $X_{1}, X_{2}, \ldots, X_{n}$, and one dependent variable, $Y$. The correlation coefficient between the independent variables is $r_{i j}(i, j \leq n)$, the correlation coefficient between the independent and dependent variables is $r_{i y}(I \leq n)$, and $P_{i}$ is the path coefficient of $X_{i}$ on $Y$. The equations formed by $r_{i j}, r_{i y}$, and $P_{i}$ are as follows:

$$
\begin{gathered}
r_{1 y}=r_{11} P_{1}+r_{12} P_{2}+\ldots+r_{1 n} P_{n} \\
r_{2 y}=r_{21} P_{1}+r_{22} P_{2}+\ldots+r_{2 n} P_{n} \\
\ldots \\
r_{n y}=r_{n 1} P_{1}+r_{n 2} P_{2}+\ldots+r_{n n} P_{n}
\end{gathered}
$$

\subsection{Geographically Weighted Regression Model}

Fotheringham proposed the geographically weighted regression (GWR) model in 1998, which extended the traditional regression framework by embedding the spatial location of the data into the regression parameters [57]. The local estimation of the parameters with GWR is expressed as follows:

$$
y_{i}=\beta_{0}\left(u_{i}, v_{i}\right)+\sum_{k} \beta_{k}\left(u_{i}, v_{i}\right) x_{i k}+\varepsilon_{i} i=1,2, \ldots, n
$$

where $i$ is the number of sample points, $k$ is the number of independent variables, $y_{i}$ is the dependent variable in the $i$ th location, $x_{i k}$ is the $i$ th value of the $k$ th independent variable, $\left(u_{i}, v_{i}\right)$ is the coordinate of the $i$ th point, $\beta_{0}\left(u_{i}, v_{i}\right)$ is the intercept value, $\beta_{k}\left(u_{i}, v_{i}\right)$ is the regression coefficient of the continuous function, and $\varepsilon_{i}$ is the model residual.

To calculate the spatial distribution of the weightings, the optimal bandwidth is required. Cross-Validation (CV) or the Akaike Information Criterion (AIC) is usually used for this calculation [58]. In this study, the AIC was chosen and was fixed by the maximum likelihood principle to determine the optimal bandwidth. 
This study adopted the GWR model to show the spatial distribution of the impact factors. The WF of crop production was treated as the dependent variable, and the impact factors of WF were regarded as the independent variables.

\subsection{Data Sources}

Using the average annual precipitation $(608.3 \mathrm{~mm})$ during 1958-2016 as a baseline, years in which the precipitation was $>20 \%$ higher than the baseline were defined as humid years, years in which the precipitation was $>20 \%$ lower were defined as drought years, and years in which the precipitation was within $10 \%$ higher or lower than the baseline were normal years $[59,60]$. According to the precipitation characteristics and the available data sources for the WF calculation, the years 2000 (416.3 mm), 2008 $(580.0 \mathrm{~mm})$, and $2016(759.3 \mathrm{~mm})$ were categorized as drought, normal and humid years, respectively.

The data covered meteorological data and agricultural data. The meteorological data (2000-2016) for Jilin Province were obtained from the China Meteorological Data Sharing Service System [61] and included the monthly average minimum temperature, monthly average maximum temperature, relative humidity, wind speed, sunshine hours, and precipitation. The agricultural data, including crop sowing area, crop yield, agricultural machinery power, consumption of chemical fertilizers, effective irrigation area, mechanically cultivated area, and mechanically seeded area, were obtained from field investigations, literature review, and the statistical yearbooks (2000-2016) of Jilin Province.

\section{Results}

\subsection{Spatiotemporal Characteristics of the WF of Crop Production}

During 2000-2016, the WF of crops exhibited a fluctuating but decreasing trend (Figure 2a). The largest WF of crops was $1.46 \mathrm{~m}^{3} / \mathrm{kg}$ in 2000, while the smallest WF of crops was $0.96 \mathrm{~m}^{3} / \mathrm{kg}$ in 2008 (Figure 2a). Comparing the WF of rice, maize, and soybean, the WF of maize was the lowest. Because Jilin Province is located in one of the three major golden corn belts in the world, the natural conditions are suitable for maize growth, and the yield is very high, leading to lower WF than other crops. For the temporal change tendency, the WF of rice exhibited the largest downtrend, followed by the WF of soybean, while the WF of maize showed little variation (Figure $2 b-d$ ).
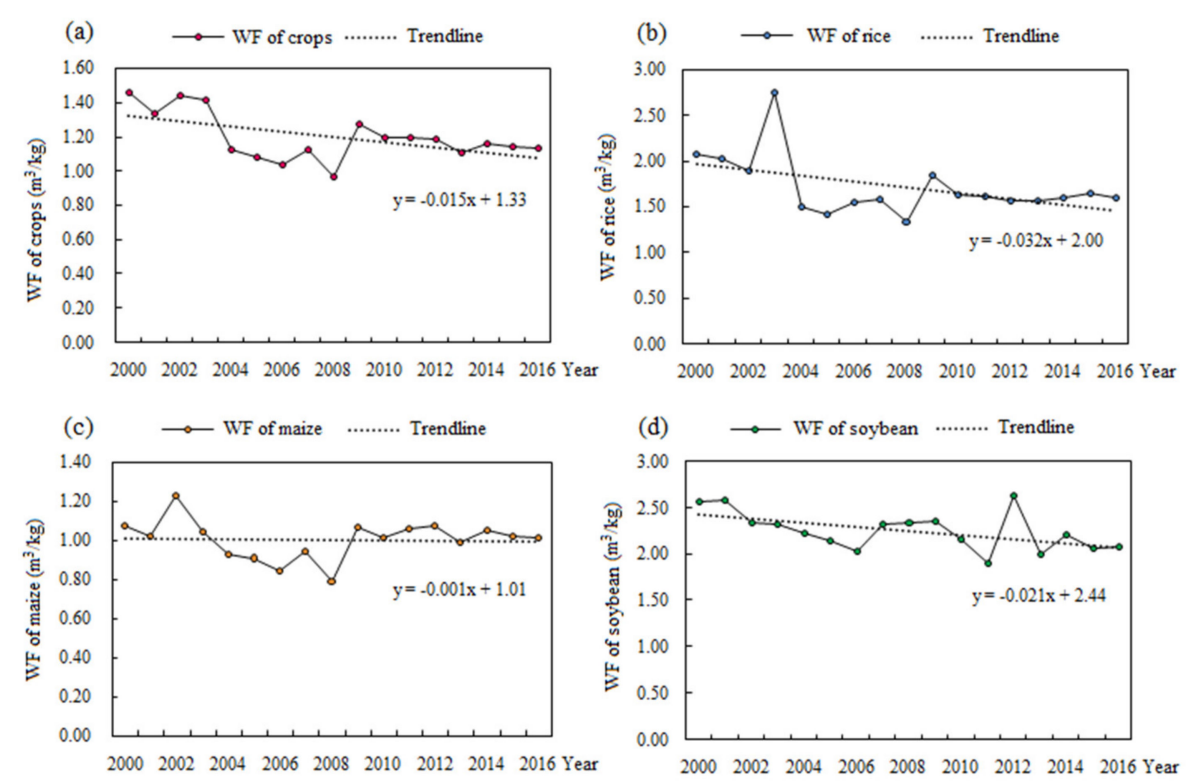

Figure 2. Interannual variability of water footprint (WF) of (a) crops, (b) rice, (c) maize, and (d) soybean.

In 2000, 2008, and 2016, the spatial distributions of the WF of all three crops and of rice, maize, and soybean are shown in Figure 3. The WF of crops in 2000, the drought year, was the highest among 
the three years due to the higher evapotranspiration and lower yield, and the highest values were distributed in the western region, followed by the eastern region, while the lowest values were in the central eastern region (Figure 3a). The WF of crops in 2008, the normal year, was the smallest because of the normal evapotranspiration and higher yield, and the areas with higher values were concentrated in the eastern region, while lower values were concentrated in the western and central regions. In 2016, the humid year, the WF of crops in the eastern region was the highest, while the lower values were located in the western and central regions. Among these three years, the WF of crops in the western region changed significantly.

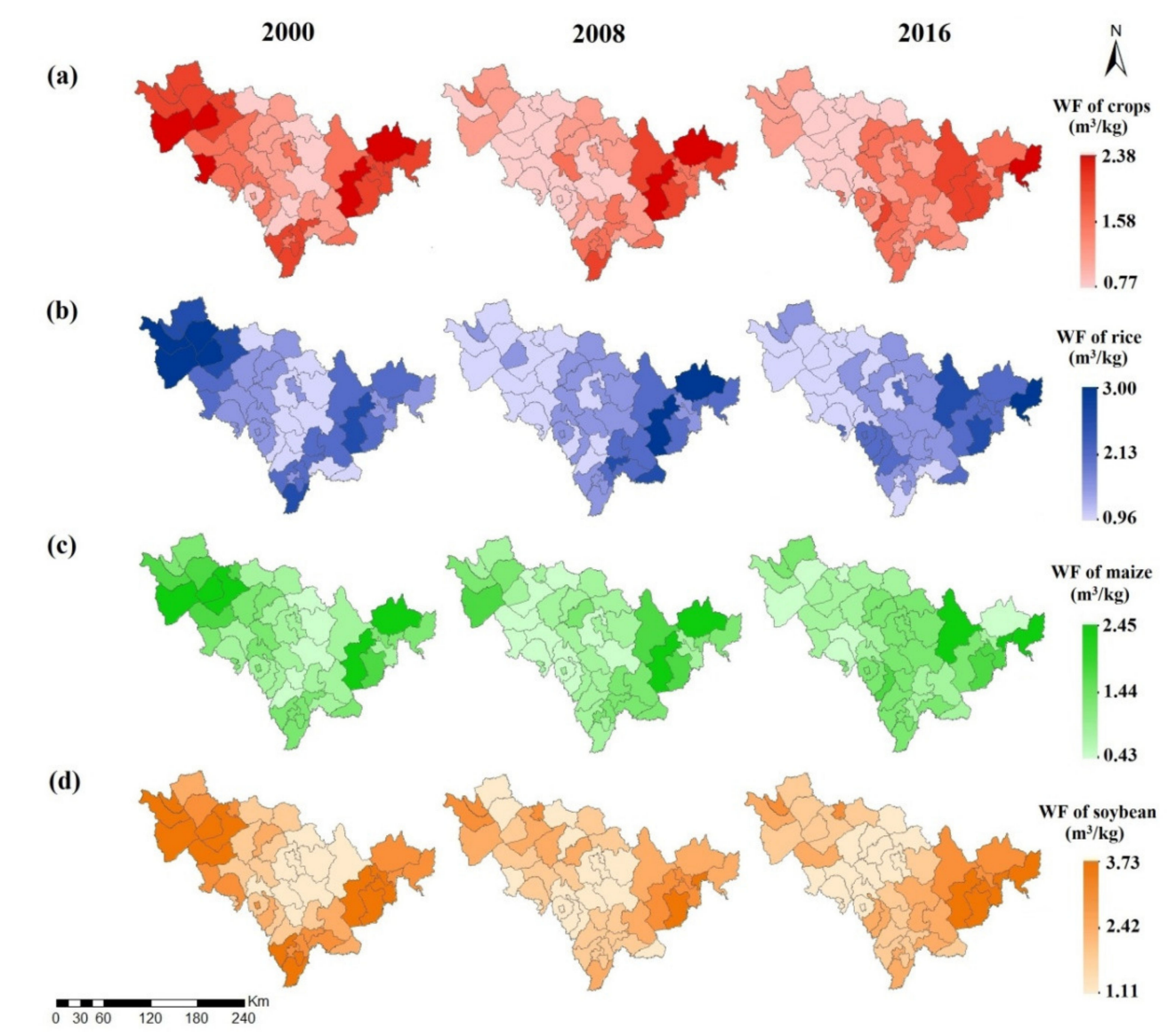

Figure 3. Spatial distributions of WF of (a) crops, (b) rice, (c) maize, and (d) soybean in 2000, 2008, and 2016.

The WF of rice in 2000, the drought year, was the largest among the three years; the highest values were distributed in the western region, and the lowest values were in the central eastern region (Figure 3b). In 2008 and 2016, the lowest WF values of rice were in the western and central regions. In 2000, the WF of maize was the highest in the western region and the lowest in the central eastern region (Figure 3c). In 2008 and 2016, the WF of maize in the central region was lower. The WF of soybean was the highest in the western region in 2000 and the lowest in the central eastern region (Figure 3d). In 2008 and 2016, the highest WF values of soybean were mainly located in the eastern region. Above all, the WF of crops, rice, maize, and soybean had similar spatial variations.

\subsection{Analysis of the Impact Factors for the WF of Crop Production}

The climatic conditions and agricultural inputs were the most important factors for crop WF. To analyze the relationships between the crop WF and its impact factors, the path analysis used climatic and agricultural input factors as the independent variables, and crop WF as the dependent variable. 
The climatic factors included the minimum temperature $\left(\mathrm{X}_{1},{ }^{\circ} \mathrm{C}\right)$, maximum temperature $\left(\mathrm{X}_{2},{ }^{\circ} \mathrm{C}\right)$, accumulated temperature $\left(X_{3},{ }^{\circ} \mathrm{C}\right)$, relative humidity $\left(X_{4}, \%\right)$, wind speed $\left(X_{5}, \mathrm{~m} / \mathrm{s}\right)$, sunshine hours $\left(X_{6}, h\right)$, and precipitation $\left(X_{7}, \mathrm{~mm}\right)$, which reflected the effects of natural conditions on crop growth and water consumption. The average temperature was chosen as the impact factor for crop WF in the previous studies $[22,25,26]$, while this study chose accumulated temperature as the impact factor rather than average temperature. Compared with average temperature, the accumulated temperature is the sum of the daily average temperature of $\geq 10^{\circ} \mathrm{C}$ during the crop growing period [62], determines the length of crop growing period, and is more accurate and reasonable to reflect the impact of temperature on the crop growth. The agricultural input factors included the agricultural machinery power $\left(X_{8}, \mathrm{~kW}\right)$, chemical fertilizer consumption $\left(X_{9}, \mathrm{~kg}\right)$, effective irrigation area $\left(X_{10}, \mathrm{hm}^{2}\right)$, mechanically cultivated area $\left(X_{11}, \mathrm{hm}^{2}\right)$ and mechanically seeded area $\left(X_{12}, \mathrm{hm}^{2}\right)$, which reflected the effects of human interfered conditions on crop growth and water consumption.

The method of path analysis can not only show the impact extent of each factor under different rainfall years but also identify the most influential factors. The path coefficients of the impact factors on the WF of crop production revealed that in 2000, the drought year, the impacts of the climatic factors from high to low were $X_{7}, X_{3}, X_{2}, X_{6}, X_{1}, X_{4}$, and $X_{5}$ (Table 4). The climatic factor with the largest effect was precipitation $\left(X_{7}\right)$, followed by accumulated temperature $\left(X_{3}\right)$, and both reached a statistically significant level $(p<0.01)$. Precipitation had a positive impact on the WF of crop production because precipitation was a source of blue water and green water for crop growth, which affected the amount of general water resources consumed in crop production. However, accumulated temperature had a negative impact on the WF of crop production since the accumulated temperature controlled the rate of crop metabolic processes, further influencing crop growth. Increasing the accumulated temperature could accelerate crop photosynthesis, increase crop yield, and decrease the WF of crop production.

Table 4. Path coefficients of the impact factors on the water footprint (WF) of crop production in 2000, 2008, and 2016.

\begin{tabular}{ccccc}
\hline & & $\mathbf{2 0 0 0}$ & $\mathbf{2 0 0 8}$ & $\mathbf{2 0 1 6}$ \\
\hline \multirow{5}{*}{ Climatic Factors } & Minimum temperature $\left(X_{1}\right)$ & 0.472 & 0.406 & 0.603 \\
& Maximum temperature $\left(X_{2}\right)$ & 0.787 & 0.554 & 0.504 \\
& Accumulated temperature $\left(X_{3}\right)$ & $-0.829 *$ & $-0.981^{* *}$ & $-1.156^{*}$ \\
& Relative humidity $\left(X_{4}\right)$ & -0.205 & -0.195 & -0.242 \\
& Wind speed $\left(X_{5}\right)$ & -0.099 & 0.132 & 0.341 \\
& Sunshine hours $\left(X_{6}\right)$ & 0.518 & -0.589 & 0.272 \\
Agricultural Input & Precipitation $\left(X_{7}\right)$ & $1.371^{* *}$ & $0.909 *$ & 0.790 \\
\hline Factors & Agricultural machinery power $\left(X_{8}\right)$ & -0.481 & $-0.704^{*}$ & $-2.951^{* *}$ \\
& Chemical fertilizers consumption $\left(X_{9}\right)$ & -0.192 & -0.560 & $-1.487^{* *}$ \\
& Effective irrigation area $\left(X_{10}\right)$ & -0.688 & -0.363 & -0.183 \\
& Mechanically cultivated area $\left(X_{11}\right)$ & 0.012 & 0.367 & 0.404 \\
& Mechanically seeded area $\left(X_{12}\right)$ & 0.053 & 0.152 & 0.412 \\
\hline
\end{tabular}

$p$-values marked with ${ }^{* *}$ and ${ }^{*}$ indicate significance at $p<0.01$ and $p<0.05$, respectively.

For the agricultural input factors, their impacts from high to low were $X_{10}, X_{8}, X_{9}, X_{12}$, and $X_{11}$. The effective irrigation area $\left(X_{10}\right)$ had a larger impact than other agricultural inputs because, in the drought year, irrigation made up for the lack of natural rainfall, ensured normal crop growth, and tended to promote crop yield, further decreasing the WF of crop production.

In 2008, the normal year, the impacts of climatic factors from high to low were $X_{3}, X_{7}, X_{6}, X_{2}, X_{1}$, $X_{4}$, and $X_{5}$. Accumulated temperature $\left(X_{3}\right)$ had the strongest influence on the WF of crop production and reached a significance level of $p<0.01$. Among the agricultural input factors, the impacts from high to low were $X_{8}, X_{9}, X_{11}, X_{10}$, and $X_{12}$, and agricultural machinery power $\left(X_{8}\right)$ had the largest impact on the WF of crop production, reaching a significance level of $p<0.05$. 
In 2016, the humid year, the impacts of climatic factors from high to low were $X_{3}, X_{7}, X_{1}, X_{2}$, $X_{5}, X_{6}$, and $X_{4}$. The most important factor was accumulated temperature $\left(X_{3}\right)$, but the significance level decreased to $p<0.05$. The impacts of agricultural inputs from high to low were $X_{8}, X_{9}, X_{12}, X_{11}$, and $X_{10}$. The agricultural machinery power $\left(X_{8}\right)$ and chemical fertilizer consumption $\left(X_{9}\right)$ had the strongest influence, and both reached a significance level of $p<0.01$.

Above all, in the drought year, precipitation and the effective irrigation area were the most influential factors. In normal and humid years, accumulated temperature was the most important climatic factor, and machinery power and chemical fertilizer consumption were the most important agricultural input factors.

\subsection{Spatial Characteristics of the Impact Factors for the WF of Crop Production}

Based on the results of path analysis, using a geographically weighted regression model, the spatial variations of the most important climatic factors (precipitation and accumulated temperature) and the agricultural input factors (machinery power, chemical fertilizer consumption, and effective irrigation area) were analyzed. The $R^{2}$ and adjusted $R^{2}$ values in the model under AIC were approximately 0.700 , both representing almost $70 \%$ of the total variance in the WF of crop production (Table 5).

Table 5. $R^{2}$ and adjusted $R^{2}$ under the Akaike Information Criterion (AIC) in the geographically weighted regression (GWR) model.

\begin{tabular}{ccc}
\hline & $\mathbf{R}^{\mathbf{2}}$ & Adjusted $\mathbf{R}^{\mathbf{2}}$ \\
\hline Precipitation & 0.754 & 0.716 \\
Accumulated temperature & 0.752 & 0.697 \\
Machinery power & 0.773 & 0.729 \\
Chemical fertilizer consumption & 0.756 & 0.693 \\
Effective irrigation area & 0.703 & 0.669 \\
\hline
\end{tabular}

Among the three years, precipitation in the drought year had a greater impact on the WF of crop production (Figure 4a), which was consistent with the result of the path analysis. In 2000, the drought year, the areas with the largest effect from precipitation were distributed in the western and central regions. In 2008, the normal year, precipitation also had a larger impact in the western and central regions, but the areas experiencing stronger effects from precipitation shrank. In 2016, the humid year, the greatest effect of precipitation was mainly distributed in the central and central eastern regions. Therefore, as precipitation increased, the areas experiencing stronger effects of precipitation gradually decreased. The uneven distribution of rainfall in the western and central regions was very obvious. Because of water shortage $(15 \%$ and $8 \%$ of the province's total water resources in the central and western regions, respectively [37]) and vast area of cultivated land ( $45 \%$ and $29 \%$ of the province's total sown area in the central and western regions, respectively [34]), when there was less rainfall in the western and central regions, the precipitation had a larger impact on the amounts of blue and green water, further influencing the WF of crop production.

In Jilin Province, the impact of accumulated temperature on the WF of crop production was negative (Figure $4 \mathrm{~b}$ ). In 2000, the drought year, the impact of accumulated temperature was the greatest in the eastern region. Due to the mountainous topography, the accumulated temperature in the eastern region was lower than that in the other regions, and the diurnal temperature varied greatly; thus, the change in temperature had a larger impact on crop growth and crop WF. In 2008, the normal year, the greatest impact of accumulated temperature was also located in the eastern region. In 2016, the humid year, except in a small part of the eastern region, the greater impact of accumulated temperature was mainly in the western region, which might be attributed to the combined influences of favorable temperature and precipitation. 
(a)

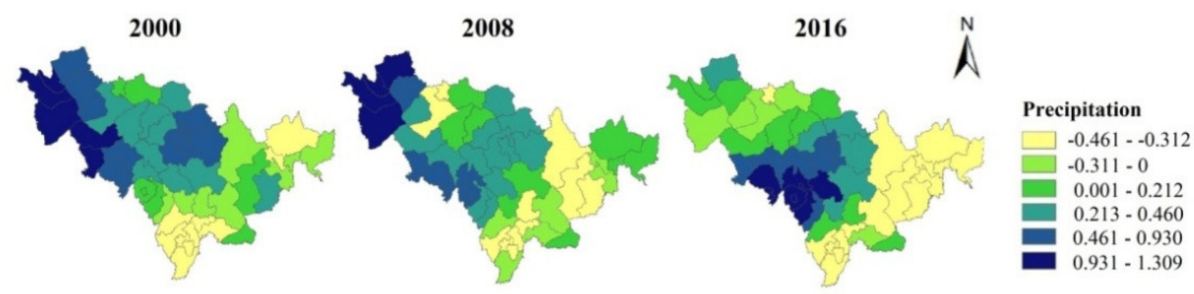

(b)

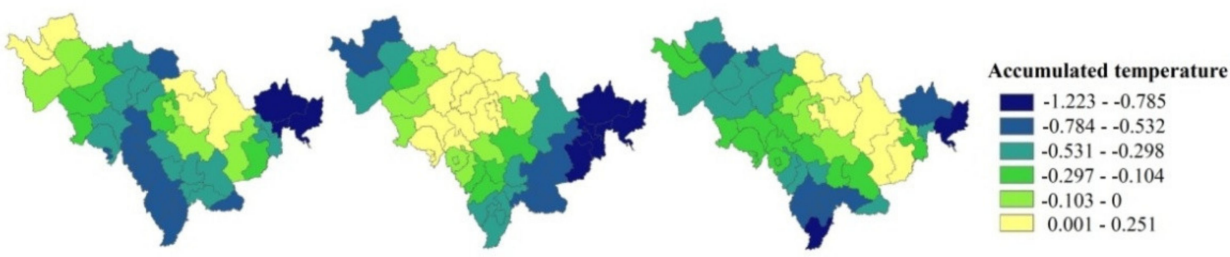

(c)

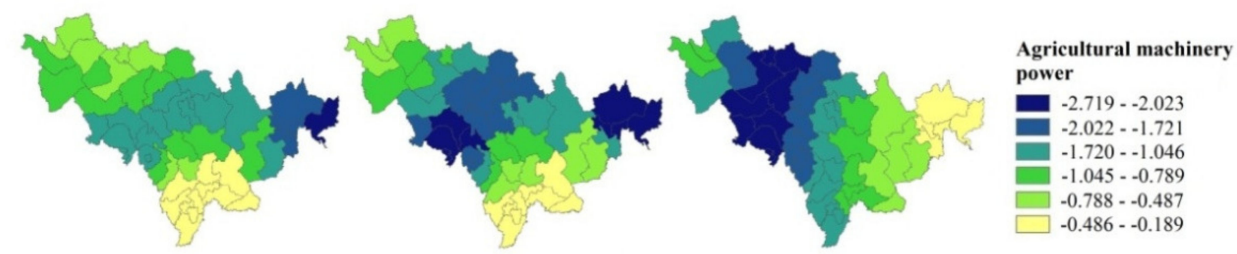

(d)
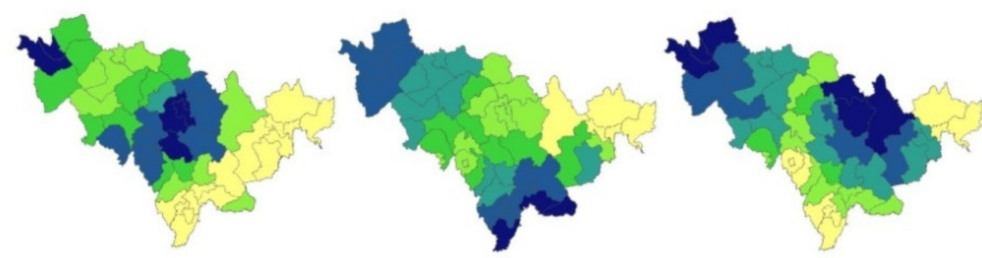

Chemical fertilizer consumption

$-1.355--0.885$ $-0.884--0.632$ $-0.631--0.498$
$-0.497--0.204$ $-0.497--0.204$

(e)
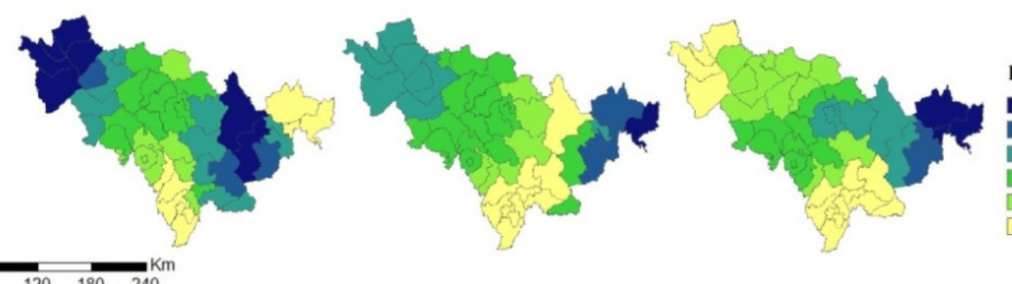

Effective irrigation area $-0.100-0$

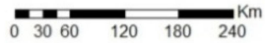

Figure 4. Spatial variation in the regression coefficients of (a) precipitation, (b) accumulated temperature, (c) agricultural machinery power, (d) chemical fertilizer consumption, and (e) effective irrigation area in 2000, 2008, and 2016.

Agricultural machinery power had a negative impact on the WF of crop production (Figure 4c). In 2000, the impact of machinery power on the WF of crop production was not significant. In 2008, the impact of machinery power became larger and was mainly concentrated in the central region. In 2016, machinery power had a more significant impact on the WF of crop production than in 2008 , and the areas experiencing greater effects expanded, covering the central and western regions. To obtain a high and steady crop yield, a substantial amount of machinery power is used in crop production. This power had a positive impact on the crop yield and a negative impact on the WF of crop production. The arable land in the central and western regions is vast and flat, suitable for mechanization. Thus, the effects of agricultural machinery power on crop WF were larger than that in other regions. Moreover, with the rapid development of the economy in the central region, the input of agricultural machinery power was the largest among regions, and the effect of agricultural machinery power on crop WF was also the most significant.

The impact of chemical fertilizer consumption on the WF of crop production was negative in Jilin Province (Figure 4d). In 2000, the area experiencing a greater effect of chemical fertilizer consumption was distributed in the central eastern region. In 2008, the impact of chemical fertilizer consumption was 
larger in the western and part of the eastern regions. Chemical fertilizer consumption had the largest impact in 2016 among the three years, and the areas experiencing a greater impact from chemical fertilizer consumption expanded. Fertilization is one of the main countermeasures for crop production, showing a gradually increasing tendency. The areas with low soil fertility are usually fertilized with more fertilizer. Therefore, the larger effects of chemical fertilizer consumption on the crop WF were in the western and eastern regions.

The impact of the effective irrigation area on the WF of crop production in 2000, the drought year, was the largest among the three years, and the major influenced area was distributed in the western region and part of the eastern region (Figure 4e). In 2008 and 2016, the normal and humid years, the impact of the effective irrigation area decreased, and the area experiencing a greater impact was only distributed in part of the eastern region. The increasing rainfall gradually met the water demands of crop growth, and the requirement for irrigation decreased.

\section{Discussion}

WF accounting is the basis for measuring water consumption of crop production, while different calculation options would cause different results. Comparing the WF in this study with those of earlier studies, discrepancies were shown (Table 6). The average WF of rice in this study $\left(1.72 \mathrm{~m}^{3} / \mathrm{kg}\right.$ ) was similar to that in Chapagain and Hoekstra $\left(1.75 \mathrm{~m}^{3} / \mathrm{kg}\right)$ [16], larger than those in Mekonnen and Hoekstra $\left(1.67 \mathrm{~m}^{3} / \mathrm{kg}\right)$ [15] and Sun et al. $\left(1.29 \mathrm{~m}^{3} / \mathrm{kg}\right)$ [63], whereas much smaller than that in Zhao et al. $\left(2.90 \mathrm{~m}^{3} / \mathrm{kg}\right)$ [64]. The average WF of maize in this study $\left(1.03 \mathrm{~m}^{3} / \mathrm{kg}\right)$ was smaller than those in Mekonnen and Hoekstra $\left(1.22 \mathrm{~m}^{3} / \mathrm{kg}\right)$ [15] and Gerbens-Leenes and Hoekstra $\left(1.13 \mathrm{~m}^{3} / \mathrm{kg}\right)$ [65] but larger than those in Sun et al. $\left(0.88 \mathrm{~m}^{3} / \mathrm{kg}\right)$ [63] and Zhao et al. $\left(0.80 \mathrm{~m}^{3} / \mathrm{kg}\right)$ [64]. The average WF of soybean was $2.06 \mathrm{~m}^{3} / \mathrm{kg}$ in this study, which was similar to that in Zhao et al. [64] but smaller than that in Mekonnen and Hoekstra [15].

Table 6. Comparison of WF of rice, maize, and soybean in earlier studies and this study.

\begin{tabular}{cccccc}
\hline Data Source & Study Area & Study Period & \multicolumn{3}{c}{ WF of Crop $\left(\mathbf{m}^{\mathbf{3}} / \mathbf{k g}\right)$} \\
\cline { 4 - 6 } & & $W_{\text {rice }}$ & WF $_{\text {maize }}$ & WF $_{\text {soybean }}$ \\
\hline $\begin{array}{c}\text { Mekonnen and } \\
\text { Hoekstra [15] }\end{array}$ & Jilin Province & $1996-2005$ & 1.67 & 1.22 & 2.15 \\
\hline $\begin{array}{c}\text { Chapagain and } \\
\text { Hoekstra [16] }\end{array}$ & Jilin Province & 2000-2004 & 1.75 & - & - \\
\hline Sun et al. [63] & Jilin Province & $1999-2007$ & 1.29 & 0.88 & - \\
\hline Zhao et al. [64] & Jilin Province & $1961-1990$ & 2.90 & 0.80 & 2.00 \\
\hline $\begin{array}{c}\text { Gerbens-Leenes and } \\
\text { Hoekstra [65] }\end{array}$ & Jilin Province & $1996-2005$ & - & 1.13 & - \\
\hline This study & Jilin Province & $2000-2016$ & 1.72 & 1.03 & 2.06 \\
\hline
\end{tabular}

The main reason for the discrepancy between the study of Mekonnen and Hoekstra [15] and this study was due to different calculation frameworks. The grid-based dynamic water balance model was used in Mekonnen and Hoekstra's study to calculate the crop water requirement. However, this study used the CROPWAT model and adopted different options to calculate different crop water consumptions, the 'crop water requirement option' for the water consumption of rice, and the 'irrigation schedule option' for the water consumption of maize and soybean. Maize and soybean were not irrigated fully during their growth, so the $W F_{\text {maize }}$ and $W F_{\text {soybean }}$ under the 'irrigation schedule option' were lower than those under the 'crop water requirement option'. For the calculation of $W F_{\text {rice }}$ in this study, the amount of percolation to groundwater during rice growth was included, which was also considered in the study of Chapagain and Hoekstra [16] and was excluded in the study of Mekonnen and Hoekstra [15]. In the study of Sun et al. [63], $W F_{\text {rice }}$ and $W F_{\text {maize }}$ only included their green WF 
and blue WF and did not calculate their gray WF. The crop yield in Zhao et al. [64] was calculated by the aboveground biomass, different from the crop yield in the statistical yearbooks. Additionally, the different study periods and crop varieties might also cause some of the discrepancies.

Identifying the most influential factors of crop WF would be conducive to optimizing farmland management and achieving sustainable agricultural production. However, the impact factors may vary under different conditions and in different regions. Studying with multiple scenarios and multiple methods would be more reflective of the real situation and changes in impact factors. In previous studies, only one analysis method was usually used for the impact factors of crop WF, while this study adopted two complementary methods (the path analysis and geographically weighted regression model) to identify the influence of factors, and chose typical rainfall years of the drought, normal, and humid to analyze the impact factors. The path analysis showed the extent of the impact factors on the crop WF in different rainfall years and identified the most influential factors. The geographically weighted regression model revealed the spatial variations of the impact factors and was conducive to obtaining the optimal managing factors in different regions.

The results for the most influential factors in this study were compared with those from earlier studies (Table 7). In this study, the most important climatic factor varied in Jilin Province in years under different levels of rainfall. Precipitation was the most important climatic factor in the drought year, and accumulated temperature was the most important climatic factor in the normal and humid years; these results are inconsistent with earlier studies. Sun et al. [25] analyzed the impact factors for the WF of maize in Beijing and found that the most important climatic factor was precipitation, which was similar to the findings of this study. In contrast, accumulated temperature was also an important climatic factor in this study. Accumulated temperature determines the length of the crop growing period and influences the crop yield. Thus, this difference is related to the locations of the different study areas. Jilin Province is located in Northeast China, and the accumulated temperature during crop growth is lower than that in Beijing; therefore, the crop growing process was influenced more by temperature in Jilin Province than in Beijing.

Table 7. Comparison of the most important climatic factors between earlier studies and this study.

\begin{tabular}{ccccc}
\hline Data Source & Study Area & Crop & Study Period & $\begin{array}{c}\text { Most Important } \\
\text { Climatic Factor }\end{array}$ \\
\hline Sun et al. [25] & Beijing & Maize & $1978-2008$ & Precipitation \\
\hline Sun et al. [26] & China & Wheat & $2001-2010$ & Sunshine hours \\
\hline Han et al. [29] & $\begin{array}{c}\text { People's Victory Canal } \\
\text { irrigation area }\end{array}$ & Winter wheat & $1961-2013$ & Precipitation \\
\hline Arunrat et al. [21] & Thailand & Rice & $2017-2018$ & Precipitation \\
\hline Govere et al. [23] & Zimbabwe & Wheat & $1980-2010$ & Precipitation \\
\hline Zemba and Obi [24] & Nigeria & Sugarcane & $1981-2013$ & Precipitation \\
\hline & & & 2000 (drought) & Precipitation \\
\cline { 4 - 5 } This study & Jilin Province & $\begin{array}{c}\text { Rice, maize, } \\
\text { soybean }\end{array}$ & 2008 (normal) & $\begin{array}{c}\text { Accumulated } \\
\text { temperature }\end{array}$ \\
\cline { 3 - 4 } & & & 2016 (humid) & $\begin{array}{c}\text { Accumulated } \\
\text { temperature }\end{array}$ \\
\hline
\end{tabular}

In addition, Sun et al. [26] analyzed the impact factors of the WF of wheat in China and discovered that sunshine hours were the most important climatic factor influencing the WF of wheat. This discrepancy was attributed to the crop species. Wheat is a long-sunshine-type crop that requires $8 \sim 12 \mathrm{~h}$ of sunshine per day to ensure its normal heading and flowering. Because of this special growth characteristic, sunshine hours have a larger impact on the WF of wheat. In a study by Han et al. [29], precipitation was the most important climatic factor influencing the WF of winter wheat in the People's Victory Canal irrigation area of China. This irrigation area is located in the Central Plains and has a 
warm temperate continental monsoon climate. Winter wheat is planted in September or October and harvested in April or May of the next year, with less rainfall during this period. The jointing-heading period of winter wheat is the key period of water demand for wheat growth; thus, precipitation became the crucial climatic factor for winter wheat growth. In the study of Arunrat et al. [21], precipitation was more important for the rice water consumption in Thailand, since their study area was located in the lowland with much rainfall and the rainy season dominated the crop growing period. Precipitation was also more influential to the water use of wheat production in Zimbabwe and the sugarcane in Nigeria, due to the tropical climate in the two study areas, characterized by special lasting wet seasons [23,24].

With increasing human activities, changes in agricultural inputs have influenced the development of agricultural modernization. This study found that the effective irrigation area was the most important input factor in the drought year, and the machinery power and chemical fertilizer consumption were the most important input factors in the normal and humid years. Because of the low natural rainfall, irrigation became necessary to maintain normal crop growth in the drought year; with increasing rainfall, the suitable climatic conditions helped increase the effect of machinery on crop yield. This result was different from those of earlier studies due to the crop species, study periods, and study areas (Table 8). In the studies of Sun et al. [25] and Duan et al. [27], the most important input factor for the WF of maize in Beijing and Northeast China was the agricultural machinery power. During their study periods, the late 20th century and early 21st century, machinery power had been gradually applied to crop production, especially for maize sowing and harvesting because of the wide and concentrated coverage. Therefore, the benefit of machinery for increasing maize yield was more obvious than the benefit to other crops, and machinery had a larger impact on the WF of maize than on the WF of other crops. In the study of Han et al. [29], the effective irrigation area was the most important input factor. The People's Victory Canal irrigation area is a typical irrigation area in China, and irrigation is very important for ensuring normal winter wheat growth in that area. Darre et al. [30] found that irrigation was crucial in the water consumption for maize and soybean production in Uruguay. Due to the special climate and soil conditions, irrigated farming was more beneficial to the local crop yield. Irrigation was also more influential to the wheat water use in Zimbabwe, because of the climatic condition and special growing season, approximately $80 \%$ of the wheat was irrigated in Zimbabwe [23]. In the study of Lovarelli et al. [31], fertilization could replenish soil nutrients and ensure the normal maize production in Northern Italy.

Table 8. Comparison of the most important agricultural input factors between earlier studies and this study.

\begin{tabular}{ccccc}
\hline Data Source & Study Area & Crop & Study Period & $\begin{array}{c}\text { Most Important } \\
\text { Agricultural Input } \\
\text { Factor }\end{array}$ \\
\hline Sun et al. [25] & Beijing & Maize & $1978-2008$ & Machinery power \\
\hline Duan et al. [27] & Northeast China & Maize & $1998-2012$ & Machinery power \\
\hline Han et al. [29] & $\begin{array}{c}\text { People's Victory Canal } \\
\text { irrigation area }\end{array}$ & Winter wheat & $1961-2013$ & Effective irrigation area \\
\hline Darre et al. [30] & Uruguay & Maize, soybean & $1996-2005$ & Irrigation \\
\hline Govere et al. [23] & Zimbabwe & Wheat & $1980-2010$ & Irrigation \\
\hline Lovarelli et al. [31] & Northern Italy & Maize & $2011-2015$ & Fertilization \\
\hline This study & Jilin Province & $\begin{array}{c}\text { Rice, maize, } \\
\text { soybean }\end{array}$ & 2000 (drought) & Effective irrigation area \\
\cline { 3 - 5 } & & & 2016 (humid) & $\begin{array}{c}\text { Machinery power and } \\
\text { Chemical fertilizers }\end{array}$ \\
\hline
\end{tabular}

This study showed that the most influential factors for the crop WF varied not only among years under different levels of rainfall but also between different regions (Table 9). In the eastern and central eastern regions of Jilin Province, water resources are abundant, and water is not the limiting factor for 
crop production. Accumulated temperature and chemical fertilizer consumption had a larger impact on crop WF. This region is a mountainous area, the temperature controls crop growth, and the gray WF of crop production caused by diffuse pollution were larger than those in other regions due to the influence of the higher slopes. To avoid soil erosion and water pollution, chemical fertilizers should be rationally consumed to ensure yield and increasing the amount of organic fertilizers, popularizing crop rotation, or intercropping should be encouraged [66].

Table 9. Most important climatic and agricultural input factors in the four regions of Jilin Province.

\begin{tabular}{|c|c|c|c|c|c|}
\hline & $\begin{array}{c}\text { Most } \\
\text { Important } \\
\text { Factors }\end{array}$ & Eastern & $\begin{array}{l}\text { Central } \\
\text { Eastern }\end{array}$ & Central & Western \\
\hline \multirow[t]{2}{*}{ Drought } & Climatic factor & $\begin{array}{l}\text { Accumulated } \\
\text { temperature }\end{array}$ & $\begin{array}{l}\text { Accumulated } \\
\text { temperature }\end{array}$ & & Precipitation \\
\hline & $\begin{array}{l}\text { Agricultural } \\
\text { input factor }\end{array}$ & $\begin{array}{c}\text { Effective } \\
\text { irrigation area }\end{array}$ & $\begin{array}{l}\text { Chemical } \\
\text { fertilizers }\end{array}$ & $\begin{array}{c}\text { Effective } \\
\text { irrigation area }\end{array}$ & $\begin{array}{c}\text { Effective } \\
\text { irrigation area }\end{array}$ \\
\hline \multirow{2}{*}{ Normal } & Climatic factor & $\begin{array}{l}\text { Accumulated } \\
\text { temperature }\end{array}$ & $\begin{array}{l}\text { Accumulated } \\
\text { temperature }\end{array}$ & $\begin{array}{l}\text { Accumulated } \\
\text { temperature }\end{array}$ & Precipitation \\
\hline & $\begin{array}{l}\text { Agricultural } \\
\text { input factor }\end{array}$ & $\begin{array}{l}\text { Chemical } \\
\text { fertilizers }\end{array}$ & $\begin{array}{l}\text { Chemical } \\
\text { fertilizers }\end{array}$ & $\begin{array}{c}\text { Machinery } \\
\text { power }\end{array}$ & $\begin{array}{c}\text { Machinery } \\
\text { power }\end{array}$ \\
\hline \multirow[t]{2}{*}{ Humid } & Climatic factor & $\begin{array}{l}\text { Accumulated } \\
\text { temperature }\end{array}$ & $\begin{array}{l}\text { Accumulated } \\
\text { temperature }\end{array}$ & $\begin{array}{l}\text { Accumulated } \\
\text { temperature }\end{array}$ & $\begin{array}{c}\text { Accumulated } \\
\text { temperature }\end{array}$ \\
\hline & $\begin{array}{l}\text { Agricultural } \\
\text { input factor }\end{array}$ & $\begin{array}{l}\text { Chemical } \\
\text { fertilizers }\end{array}$ & $\begin{array}{l}\text { Chemical } \\
\text { fertilizers }\end{array}$ & $\begin{array}{l}\text { Machinery } \\
\text { power }\end{array}$ & $\begin{array}{l}\text { Machinery } \\
\text { power }\end{array}$ \\
\hline
\end{tabular}

In the western and central regions, water resources are in short supply, so precipitation was the most important climatic factor in the drought year, and accumulated temperature was the most important climatic factor in the normal and humid years. For the agricultural input factors, the impact of the effective irrigation area was larger in the drought year than in the other years, and the machinery power was more impactful in the normal and humid years than in the drought year. The natural rainfall was not sufficient in the drought year and could only meet a part of the water requirement for crop growth; thus, artificial irrigation became critical to crop growth, especially for rice and maize. According to the water requirements of crops and types of rainfall years, a reasonable water-saving irrigation system should be developed to increase the utilization rate of water resources.

Meanwhile, increasing the planting proportion of crops consuming less water, such as maize, should be encouraged. Besides, in the drought years, artificial irrigation (sow with water) should be increased to establish a favorable moisture condition in soil, while in the humid years, excessive irrigation is unnecessary and should be monitored properly. However, when water was not the primary limiting factor, the machinery power became the most important agricultural input factor influencing crop WF in normal and humid years. Agricultural machinery power could not only promote labor productivity but also improve the efficiency of crop production and crop yield. Popularizing agricultural mechanization is the safeguard for improving crop production in the western and central regions. Thus, identifying the most influential factors of crop WF will help formulate the corresponding countermeasures to promote crop production.

\section{Conclusions}

The most important factors influencing the WF of crop production varied among years under different levels of rainfall and in different regions. The precipitation and effective irrigation area were the most influential factors in the drought year, and accumulated temperature, machinery power, and chemical fertilizer consumption were the most influential factors in the normal and humid years. Moreover, the regional differences were clear. Accumulated temperature and chemical fertilizer consumption were the most important factors in all years in the eastern and central eastern regions 
with rich water, while precipitation and effective irrigation area were the most important factors in the drought year. Accumulated temperature and machinery power were the most important factors in the normal and humid years in the western and central regions with water shortages. The most influential factors for the WF of crop production varied with changes in the natural and human interfered conditions. Identifying the impacts of the climatic and agricultural input factors on the water consumption of crop production would be conducive to determining the optimal managing factors for sustainable agricultural production.

Author Contributions: Methodology, X.Z. and L.Q.; software, X.Z.; validation, X.Z., L.Q., and H.H.; formal analysis, X.Z.; data curation, X.Z.; writing-original draft preparation, X.Z.; writing-review and editing, X.Z., L.Q., and H.H.; funding acquisition, L.Q. and H.H. All authors have read and agreed to the published version of the manuscript.

Funding: This research was funded by the National Natural Science Foundation of China (41571526), the National Key Research and Development Project of China (2016YFA0602301) and the Key Project of National Natural Science Foundation of China (41630749).

Conflicts of Interest: The authors declare no conflict of interest.

\section{References}

1. Cao, S.H.; Ma, W.P.; Nie, L. Overview of studies on grain security in China. Asian Agric. Res. 2014, 4, 67-74. (In Chinese)

2. Rockstrom, J.; Gordon, L.; Folke, C.; Falkenmark, M.; Engwall, M. Linkages among water vapor flows, food production, and terrestrial ecosystem services. Conserv. Ecol. 1999, 3, 5. [CrossRef]

3. Casolani, N.; Cartone, A.; Postiglione, P.; Liberatore, L. Climate variability in agriculture and crop water requirement: Spatial analysis of Italian provinces. J. Clean. Prod. 2020, 262, 121331. [CrossRef]

4. Alfonso, C.; Barbieri, P.A.; Hernández, M.D.; Lewczuk, N.A.; Martínez, J.P.; Echarte, M.M.; Echarte, L. Water productivity in soybean following a cover crop in a humid environment. Agric. Water Manag. 2020, 232, 106045. [CrossRef]

5. Choudhary, M.; Panday, S.C.; Meena, V.S.; Singh, S.; Yadav, R.P.; Pattanayak, A.; Mahanta, D.; Bisht, J.K.; Stanley, J. Long-term tillage and irrigation management practices: Strategies to enhance crop and water productivity under rice-wheat rotation of Indian mid-Himalayan Region. Agric. Water Manag. 2020, 232, 106067. [CrossRef]

6. Hoekstra, A.Y.; Hung, P.Q. A quantification of virtual water flows between nations in relation to international crop trade. Water Res. 2002, 49, 203-209.

7. Hoekstra, A.Y.; Chapagain, A.K. Globalization of Water: Sharing the Planet's Freshwater Resources; Blackwell Publishing: Oxford, UK, 2008.

8. Hoekstra, A.Y.; Chapagain, A.K. The water footprints of Morocco and the Netherlands: Global water use as a result of domestic consumption of agricultural commodities. Ecol. Econ. 2007, 64, 143-151. [CrossRef]

9. Hoekstra, A.Y.; Chapagain, A.K. Water footprints of nations: Water use by people as a function of their consumption pattern. Water Resour. Manag. 2007, 21, 35-48. [CrossRef]

10. Hoekstra, A.Y.; Chapagain, A.K.; Aldaya, M.M.; Mekonnen, M.M. Water Footprint Assessment Manual: Setting the Global Standard; Earthscan: London, UK, 2011.

11. Flach, R.; Skalsky, R.; Folberth, C.; Balkovic, J.; Jantke, K.; Schneider, U.A. Water productivity and footprint of major Brazilian rainfed crops-A spatially explicit analysis of crop management scenarios. Agric. Water Manag. 2020, 233, 105996. [CrossRef]

12. Borsato, E.; Galindo, A.; Tarolli, P.; Sartori, L.; Marinello, F. Evaluation of the grey water footprint comparing the indirect effects of different agricultural practices. Sustainability 2018, 10, 3992. [CrossRef]

13. Food and Agriculture Organization (FAO). CROPWAT Model; Food and Agriculture Organization of the United Nations: Rome, Italy, 2010.

14. Mekonnen, M.M.; Hoekstra, A.Y. A global and high-resolution assessment of the green, blue and grey water footprint of wheat. Hydrol. Earth Syst. Sci. 2010, 14, 1259-1264. [CrossRef]

15. Mekonnen, M.M.; Hoekstra, A.Y. The green, blue and grey water footprint of crops and derived crop products. Hydrol. Earth Syst. Sci. 2011, 15, 1577-1592. [CrossRef] 
16. Chapagain, A.M.; Hoekstra, A.Y. The blue, green and grey water footprint of rice from production and consumption perspectives. Ecol. Econ. 2011, 70, 749-753. [CrossRef]

17. Shrestha, S.; Pandey, V.P.; Chanamai, C.; Ghosh, D.K. Green, blue and grey water footprints of primary crops production in Nepal. Water Resour. Manag. 2013, 27, 5223-5243. [CrossRef]

18. Tian, Y.H.; Ruth, M.; Zhu, D.J.; Ding, J.F.; Morris, N. A sustainability assessment of five major food crops' water footprints in China from 1978 to 2010. Sustainability 2019, 11, 6179. [CrossRef]

19. Santos, J.F.S.; Naval, L.P. Spatial and temporal dynamics of water footprint for soybean production in areas of recent agricultural expansion of the Brazilian savannah (Cerrado). J. Clean. Prod. 2020, 251, 119482. [CrossRef]

20. Cao, X.C.; Huang, X.; Huang, H.; Liu, J.; Guo, X.P.; Wang, W.G.; She, D.L. Changes and driving mechanism of water footprint scarcity in crop production: A study of Jiangsu Province, China. Ecol. Indic. 2018, 95, 444-454. [CrossRef]

21. Arunrat, N.; Pumijumnong, N.; Sereenonchai, S.; Chareonwong, U.; Wang, C. Assessment of climate change impact on rice yield and water footprint of large-scale and individual farming in Thailand. Sci. Total Environ. 2020, 726, 137864. [CrossRef]

22. Chen, S.; Wu, M.Y.; Cao, X.C.; Guo, X.P. Analysis of the characteristics and driving forces of water footprint productivity in paddy rice cultivation in China. J. Sci. Food Agric. 2020, 100, 1764-1774. [CrossRef]

23. Govere, S.; Nyamangara, J.; Nyakatawa, E.Z. Climate change signals in the historical water footprint of wheat production in Zimbabwe. Sci. Total Environ. 2020, 742, 140473. [CrossRef]

24. Zemba, A.A.; Obi, J.N. Relationship between climatic variability and water footprint of sugarcane at Dangote Sugar Company Numan, Nigeria. Glob. J. Pure Appl. Sci. 2018, 24, 103-115. [CrossRef]

25. Sun, S.K.; Wu, P.T.; Wang, Y.B.; Zhao, X.N. Temporal variability of water footprint for maize production: The case of Beijing from 1978 to 2008. Water Resour. Manag. 2013, 27, 2447-2460. [CrossRef]

26. Sun, S.K.; Wang, Y.B.; Wu, P.T. Analysis on spatial characteristics and attribution of water footprint for wheat production. Trans. Chin. Soc. Agric. Eng. 2015, 13, 142-145. (In Chinese)

27. Duan, P.L.; Qin, L.J.; Wang, Y.Q.; He, H.S. Spatiotemporal correlations between water footprint and agricultural inputs: A case study of maize production in Northeast China. Water 2015, 7, 4026-4040. [CrossRef]

28. Garofalo, P.; Ventrella, D.; Kersebaum, K.C.; Gobin, A.; Trnka, M.; Giglio, L.; Dubrovsky, M.; Castellini, M. Water footprint of winter wheat under climate change: Trends and uncertainties associated to the ensemble of crop models. Sci. Total Environ. 2019, 658, 1186-1208. [CrossRef] [PubMed]

29. Han, Y.P.; Zhang, J.Y.; Dai, X.P. Study on influencing factors of the water footprint for crop production in irrigation areas. Yellow River 2017, 2, 42-46. (In Chinese)

30. Darre, E.; Cadenazzi, M.; Mazzilli, S.R.; Rosas, J.F.; Picasso, V.D. Environmental impacts on water resources from summer crops in rainfed and irrigated systems. J. Environ. Manag. 2019, 232, 514-522. [CrossRef]

31. Lovarelli, D.; Ingrao, C.; Fiala, M.; Bacenetti, J. Beyond the water footprint: A new framework proposal to assess freshwater environmental impact and consumption. J. Clean. Prod. 2018, 172, 4189-4199. [CrossRef]

32. Wang, X.H.; Lu, W.X.; Xu, Y.J.; Zhang, G.X.; Qu, W.; Cheng, W.G. The positive impacts of irrigation schedules on rice yield and water consumption: Synergies in Jilin Province, Northeast China. Int. J. Agric. Sustain. 2016, 14, 1-12. [CrossRef]

33. Li, C.G.; Dong, H.H. Geography of Jilin Province; Beijing Normal University Publishing Group: Beijing, China, 2010.

34. Local Chronicles Compilation Committee of Jilin Province. Jilin Province Records: Natural Geographical Records; Jilin People's Press: Changchun, China, 1992.

35. Wang, J.Q.; Qin, L.J.; He, H.S. Assessing temporal and spatial inequality of water footprint based on socioeconomic and environmental factors in Jilin Province, China. Water 2019, 11, 521. [CrossRef]

36. Li, J.D.; Jia, G.H.; Sheng, L.X. Theory and Practice of Ecological Environment Development in Jilin Province; Jilin Science and Technology Press: Jilin, China, 2005.

37. Jilin Statistical Yearbook. Available online: http://tjj.jl.gov.cn/tjsj/tjnj/2017/mL/indexc.htm (accessed on 20 May 2017).

38. Statistic Bureau of Jilin Province. Statistical Bulletin of National Economic and Social Development. Available online: http://tjj.jl.gov.cn/tjsj/tjgb/ndgb/ (accessed on 5 June 2017). 
39. Ministry of Environmental Protection of China. Environmental Quality Standards for Surface Water in China (GB3838-2002); Ministry of Environmental Protection of China: Beijing, China, 2002.

40. Shen, J.; Gao, Q. Investigation and analysis of the fertilizations of rice in Jilin Province. J. Jilin Agric. Sci. 2011, 2, 40-43. (In Chinese)

41. Wang, Y.; Feng, G.Z.; Yan, L. Study on the effect of fertilizations and the efficiency of fertilizer utilization of maize in Jilin Province. J. Plant Nutr. Fert. 2016, 6, 1441-1443. (In Chinese)

42. Zhou, Y.F.; Liu, X.J.; Chen, X.G. Production and application of the technical index system of the fertilizations of soybean. Agric. Technol. 2012, 10, 18-19. (In Chinese)

43. Wang, X.H. Study on the Technology and Pattern of Water-Saving Irrigation and Water Management of Rice in Jilin Provinc. Master's Thesis, Jilin University, Changchun, China, 2012.

44. Sun, A.H. Study on Water-Fertilizer Effect and Irrigation Models of Rice in Sanjiang Plain. Ph.D. Thesis, Northeast Agricultural University, Harbin, China, 2011.

45. Xie, W.Y.; Fan, G.S. Influence of soil structure on infiltration characteristics in field soils. J. Taiyuan Univ. Technol. 2004, 35, 537-540. (In Chinese)

46. Zhu, J.W.; Lv, J.D. Study on water requirement of paddy field in Jilin. J. Irrig. Drain 1992, 11, $20-22$. (In Chinese)

47. Food and Agriculture Organization (FAO). Technical Conversion Factors for Agricultural Commodities; Food and Agriculture Organization of the United Nations: Rome, Italy, 2003.

48. Allen, R.G.; Pruitt, W.O.; Wright, J.L.; Howell, T.A.; Ventura, F.; Snyder, R. A recommendation on standardized surface resistance for hourly calculation of reference $\mathrm{ET}_{0}$ by the FAO 56 Penman-Monteith method. Agric. Water Manag. 2006, 81, 1-22. [CrossRef]

49. Allen, R.G.; Pereira, L.S.; Raes, D.; Smith, M. Crop Evapotranspiration: Guidelines for Computing Crop Water Requirements (FAO Irrigation and Drainage Paper 56); Food and Agriculture Organization: Rome, Italy, 1998.

50. United States Department of Agriculture (USDA). The Major World Crop Areas and Climatic Profiles, Agricultural Handbook No 664; World Agricultural Outlook Board, United States Department of Agriculture: Washington, DC, USA, 1994.

51. Xu, H.; Pei, Z.; Wang, P.W. Investigation and research on irrigating-sowing technology in semi-arid areas of Jilin Province. J. Jilin Agric. Sci. 1991, 3, 27-29. (In Chinese)

52. Qin, L.J.; Jin, Y.H.; Duan, P.L.; He, H.S. Field-based experimental water footprint study of sunflower growth in a semi-arid region of China. J. Sci. Food Agric. 2016, 96, 3266-3273. [CrossRef] [PubMed]

53. Yin, G.H.; Chen, W.F.; Liu, Z.X. Study on the mechanical technology of irrigating-sowing water in semi-arid areas of northern China. Res. Agric. Mod. 2007, 2, 238-240. (In Chinese)

54. Chen, L.Y.; Sang, L.J. Irrigating-sowing technology for drought resistance in western northeast China. Hortic. Seed 2015, 8, 87-88. (In Chinese)

55. Wright, S. The theory of path coefficients: A reply to Niles's criticism. Genetics 1923, 8, 239-255. [PubMed]

56. Du, J. Implementations of path analysis in Excel and SPSS. J. Shaanxi Meteorol. 2012, 1, 15-18. (In Chinese)

57. Fotheringham, A.S.; Brunsdon, C.F.; Charlton, M. Geographically weighted regression modeling spatial non-stationarity. J. R. Stat. Soc. Ser. D Stat. 1998, 3, 431-443.

58. Xuan, H.Y.; Li, S.P.; Liu, S.Q. The model and fitting of geographical weighted regression. J. Gansu Sci. 2007, 1, 51-52. (In Chinese)

59. General Administration of Quality Supervision, Inspection and Quarantine of the People's Republic of China; Standardization Administration of China. Standard for Hydrological Information and Hydrological Forecasting (GB/T22482-2008); General Administration of Quality Supervision: Beijing, China, 2008.

60. Li, H.Y.; Qin, L.J.; He, H.S. Characteristics of the water footprint of rice production under different rainfall years in Jilin Province, China. J. Sci. Food Agric. 2018, 98, 3001-3013. [CrossRef]

61. Dataset of Daily Values of Climate Data from Surface Meteorological Stations in China (V3.0). Available online: http://data.cma.cn/data/cdcindex/cid/6d1b5efbdcbf9a58.html (accessed on 15 May 2017).

62. Lv, J.Y.; Yan, C.; Jia, T.Y.; Wang, F.Y.; Sun, H.C.; Dong, S.K.; Gong, Z.P. The variation of accumulated temperature in Songnen Plain and its impact on crop yield. Chin. J. Ecol. 2019, 11, 3349-3356. (In Chinese)

63. Sun, S.K.; Wu, P.T.; Wang, Y.B.; Zhao, X.N. The virtual water content of major grain crops and virtual water flows between regions in China. J. Sci. Food Agric. 2013, 93, 1427-1437. [CrossRef]

64. Zhao, Q.B.; Liu, J.G.; Khabarov, N.; Obersteiner, M.; Westphal, M. Impacts of climate change on virtual water content of crops in China. Ecol. Inform. 2014, 19, 26-34. [CrossRef] 
65. Gerbens-Leenes, W.; Hoekstra, A.Y. The water footprint of sweeteners and bio-ethanol. Environ. Int. 2012, 40, 202-211. [CrossRef]

66. Sone, J.S.; Oliveira, P.T.S.; Zamboni, P.A.P.; Vieira, N.O.M.; Carvalho, G.A.; Macedo, M.C.M.; Araujo, A.R.; Montagner, D.B.; Sobrinho, T.A. Effects of long-term crop-livestock-forestry systems on soil Erosion and water infiltration in a Brazilian Cerrado Site. Sustainability 2019, 11, 5339. [CrossRef]

(C) 2020 by the authors. Licensee MDPI, Basel, Switzerland. This article is an open access article distributed under the terms and conditions of the Creative Commons Attribution (CC BY) license (http://creativecommons.org/licenses/by/4.0/). 